\title{
ANALYSIS OF REMAINING SERVICE LIFE FOR FLEXIBLE PAVEMENT USING MECHANISTIC-EMPIRICAL METHODS
}

\author{
*Anita Rahmawati ${ }^{1}$ and Muharor Adiyasa ${ }^{1}$ \\ ${ }^{1}$ Department of Civil Engineering, Faculty of Engineering, Universitas Muhammadiyah Yogyakarta, 55182, \\ Kasihan, Bantul, Yogyakarta, Indonesia \\ *Corresponding Author, Received: 14 May 2021, Revised: 15 July 2021, Accepted: 26 Aug. 2021
}

\begin{abstract}
This study aims to analyze pavement performance to predict the remaining service life and its handling. This research utilized mechanistic-empirical methods, specifically the KENPAVE program to analyze the strain on the pavement, the AASHTO 1993 to predict the remaining service life, and the 2017 Road Pavement Design Manual (MDP 2017) to recommend alternative treatments in the form of new pavement. This study discovered a horizontal tensile strain value of 0.0002998 and a vertical compressive strain of 0.0004022 . Using the Asphalt Institute equation, the repetition value of the fatigue cracking load was 1,047,484.63 ESAL, and the repetition value of rutting load was 2,172,928.92 ESAL. Prediction of remaining service life due to traffic loads using the AASHTO 1993 equation yielded a residual service life value of $1.03 \%$ fatigue cracking in the second year and the remaining rutting service life of $24.79 \%$ in the third year. The results revealed that the pavement was unable to withstand traffic loads according to the planned age. Therefore, MDP 2017 was used to provide alternative treatments and resulted in the alternative handling presented, recommended as a treatment for the study site.
\end{abstract}

Keywords: Damage analysis, Mechanistic- empirical, KENPAVE program, Service life

\section{INTRODUCTION}

Transportation plays an essential role in supporting the progress of an area, which involves many aspects. It can be realized if transportation between regions runs smoothly and safely. Thus, it requires the availability of adequate road infrastructure.

A mechanistic-empirical method has been widely used to evaluate road performance. This mechanistic model is based on fundamental physics and determines the pavement reaction to wheel loads in terms of stress, strain, and displacement, while the empirical model applies pavement response to predict pavement life based on pavement performance [1].

Performance evaluation indicators commonly employed in flexible pavements are fatigue cracking occurring under the surface layer and permanent deformation (rutting) at the subgrade surface. Fatigue cracking and rutting are considered major failures since they have far-reaching effects on pavement performance. Estimating the stressstrain response of the pavement structure requires high accuracy. Therefore, KENPAVE software developed by Yang H. Huang P.E is required.

Research location is a provincial road with a vital role in economic development in Yogyakarta. Unfortunately, along with the development of traffic, this street has experienced visual damage. Therefore, the traffic development in the area must be followed by an appropriate level of road service to avoid disturbing the comfort of road users. It is crucial to study the necessary handling, especially concerning flexible pavement behavior. Therefore, this study aims to analyze pavement performance to predict the remaining road service life and its handling.

Road infrastructure performance service, from the stage of implementation to the planned service life keeps undergoing an increase of loading due to traffic volume, so that the road built must have reliable carrying capacity. Thus, it needs study and research to conduct about the behaviour of flexible pavement towards response of vehicle axle load or other factors. In flexible pavement structure, the load of vehicle under goes repitition has 1 (one) power failure which is assumed as evenly distributed static load, and therefore the material of pavement will provide response in the form of stress, strain, and deflection. This is closely related in order to predict the performance of pavement structure on the road of in the form of values of load repitition when reaching fatigue and rutting and to predict the remaining service life of the pavement. Performance appraisal indicator which is applied often for flexible pavement is fatigue cracking occurred bottom of the asphalt layer and permanent deformation (rutting) on the surface of subgrade. The estimate of strain response in each pavement layer structure needs carefulness and high accuracy level and therefore a software named KENPAVE developed by Yang H. Huang P.E is required [2]. 


\section{RESEARCE SIGNIFICANT}

The significant of the research are:

a. The theoretical benefit is to provide a scientific reference for the development of knowledge in the field of transportation, especially pavement analysis using empirical mechanical methods in predicting damage and remaining service life.

b. Practical benefits, providing convenience for pavement planning based on damage and remaining remaining design life.

\section{FLEXIBLE PAVEMENT}

Pavement is a relatively stable crust built on natural soil to support and distribute vehicle wheel loads [3]. According to the Department of Public Works [4], the flexible pavement has been made of a mixture of asphalt as the surface layer and grained material as the underlay. In general, flexible pavement construction consists of:

a. The surface course, which functions to hold loads of vehicle wheels and wear layer and spread the loads to the base so that other layers can carry it

b. The base course, which functions as a barrier to cross-bearing loads of the vehicle wheels, the absorption layer, and the bearing for the surface layer

c. The sub-base course, which functions to spread the wheel loads to the subgrade and the infiltration layer and prevents fine soil particles from rising to the base course

d. The subgrade, a place for laying other pavement layers.

\section{MECHANISTIC-EMPIRICAL METHODS}

According to Heliyati and Kushari [5], the concept of the mechanistic-empirical methods is the relationship between traffic loads and damage to the pavement. Several essential parameters in a flexible hardening system using this method are Poisson's ratio, modulus of elasticity, stress, strain, deflection, critical structure values, and environmental conditions [2]. A sustainable and rational approach using mechanistic-empirical methods can provide better, accurate, and more rational solutions for road designs with thin bitumen [6]. The advantages of using the mechanistic-empirical methods are as follows:

a. They can be used for the reconstruction of existing pavements and the construction of new pavements.

b. Material characteristics can be adjusted according to the material to be used.

c. The performance predictions are quite reliable. d. They accommodate changing traffic load types.

e. They predict the types of damage.

\section{KENPAVE PROGRAM}

The KENPAVE program is a pavement planning program developed by Dr. Yang Huang, P.E. This software is a combination of four separate graphics programs: layernip, kenlaver, slabnip, and kenslab. This program is written in the Visual Basic programming language and can be run on Windows 95 or higher [2]. This program evaluates flexible pavements based on stress and strain values [7]. Besides, it can be used for pavement analysis and design quickly with good accuracy and for many layers [8].

\section{DAMAGE ANALYSIS}

The vertical compressive strain above the subgrade provides an overview of rutting failure, while the horizontal tensile strain under the asphalt surface layer gives an illustration of fatigue cracking in the flexible pavement layer structure [9]. Groove cracking (rutting) on the pavement surface is the accumulation of all permanent deformations that occur from the asphalt layer, aggregate layer (base), and subgrade due to repeated loading [10]. Meanwhile, fatigue cracking is a relationship of a series of cracks, which causes small irregular pieces due to continuous repeated loading [11]. Stress is influenced by the modulus of elasticity, thickness of the pavement layer, Poisson's ratio, and traffic load. An increase in axle loads decreases the service life drastically [12], while an increase in the thickness of the pavement layer, both the surface and the base layers, will reduce the stress and strain values on the pavement [13-15]. Besides, an increase in the modulus of elasticity of the pavement layer can reduce the strain value on the pavement [16]. Equations (1) and (2) can be used to calculate the number of repetitions of allowable fatigue (Nf) and rutting $(\mathrm{Nd})$ loads in a flexible pavement structure based on fatigue and rutting damage [17].

$\mathrm{Nf}=0.0796(\varepsilon \mathrm{t})-3.291(\mathrm{E})-0.854$

with,

$\mathrm{Nf}=$ number of repetitions of the load,

$\varepsilon \mathrm{t}=$ horizontal tensile strain at the bottom of the surface layer, and

$\mathrm{E}=$ elastic modulus of the surface layer.

$\mathrm{Nd}=1.365 \times 10-9(\varepsilon \mathrm{c})-4.477$ 
with,

$\mathrm{Nd}=$ number of repetitions of the load, and

$\varepsilon \mathrm{c}=$ vertical compressive strain above the subgrade.

\section{PREDICTION OF REMAINING SERVICE LIFE}

The prediction of remaining service life is a fundamental concept for estimating the number of loads that a pavement can withstand until it collapses at a specific time due to melting and permanent deformation caused by repeated loading. The remaining service life prediction is calculated based on the actual amount of pavement traffic $(\mathrm{Np})$ and pavement traffic when the pavement reaches a failure condition due to fatigue cracking and rutting $(\mathrm{N} 1,5)$. AASHTO [18] recommended predicting the remaining service life using Eq. (3).

$\mathrm{RL}=100\left[1-\left(\frac{\mathrm{Np}}{\mathrm{N} 1,5}\right)\right]$

with,

$\mathrm{RL}=$ remaining life (\%),

$\mathrm{NP}=$ total traffic to date, and

$\mathrm{N} 1,5=$ total traffic to pavement failure.

\section{ROAD PAVEMENT DESIGN MANUAL NO. 04/SE/DB/2017}

In road pavement planning, it is necessary to consider factors affecting the function of road pavement construction services so that they can provide comfort to road users [19]. Through the Director-General of Highways, the Ministry of Public Works issued a Road Pavement Design Manual No. 04/SE/Db/2017 as a guideline for pavement design that can accommodate traffic loads during the design life following the design chart. The procedure for using this manual for flexible pavement design is as follows.

a. Determining the plan age

b. Calculating the value of CESA4 according to the plan age and traffic parameters such as traffic volume, traffic growth factors, direction and lane distribution factors, and load equivalent factors

c. Determining the traffic multiplier (TM) value

d. Calculating the CESA5

e. Determining the type of pavement using a design chart

\section{RESEARCH METHOD}

\subsection{Research Stages}

The research stages carried out in this study are as follows:

a. Conducting literature studies concerning flexible pavements, mechanistic-empirical methods, fatigue cracking and rutting, and prediction of remaining service life on flexible pavements

b. Analyzing the value of horizontal tensile stress and vertical compressive strain on existing pavements using the KENPAVE program

c. Analyzing the daily traffic value

d. Analyzing the total value of traffic growth factors

e. Determining the directional distribution factors and the lane distribution

f. Determining the value of the vehicle damage factors

g. Analyzing ESA and CESA4 values

h. Determining the traffic multiplier value

i. Analyzing the CESA5 value

j. Analyzing the repetition of the allowable fatigue loads (Nf) using Eq. (1)

k. Analyzing the repetition of the allowance rutting loads $(\mathrm{Nd})$ using Eq. (2)

1. Predicting the remaining service life of the existing pavement using Eq. (3)

$\mathrm{m}$. Recommending alternative handling in the form of new pavement according to the Road Pavement Design Manual No. 04/SE/Db/2017, tested with the KENPAVE program against allowable load repetition.

n. Concluding and offering suggestions

\subsection{Research Site}

This research was conducted on Gito Gati Street, Sleman Regency, Yogyakarta (Fig. 1). 


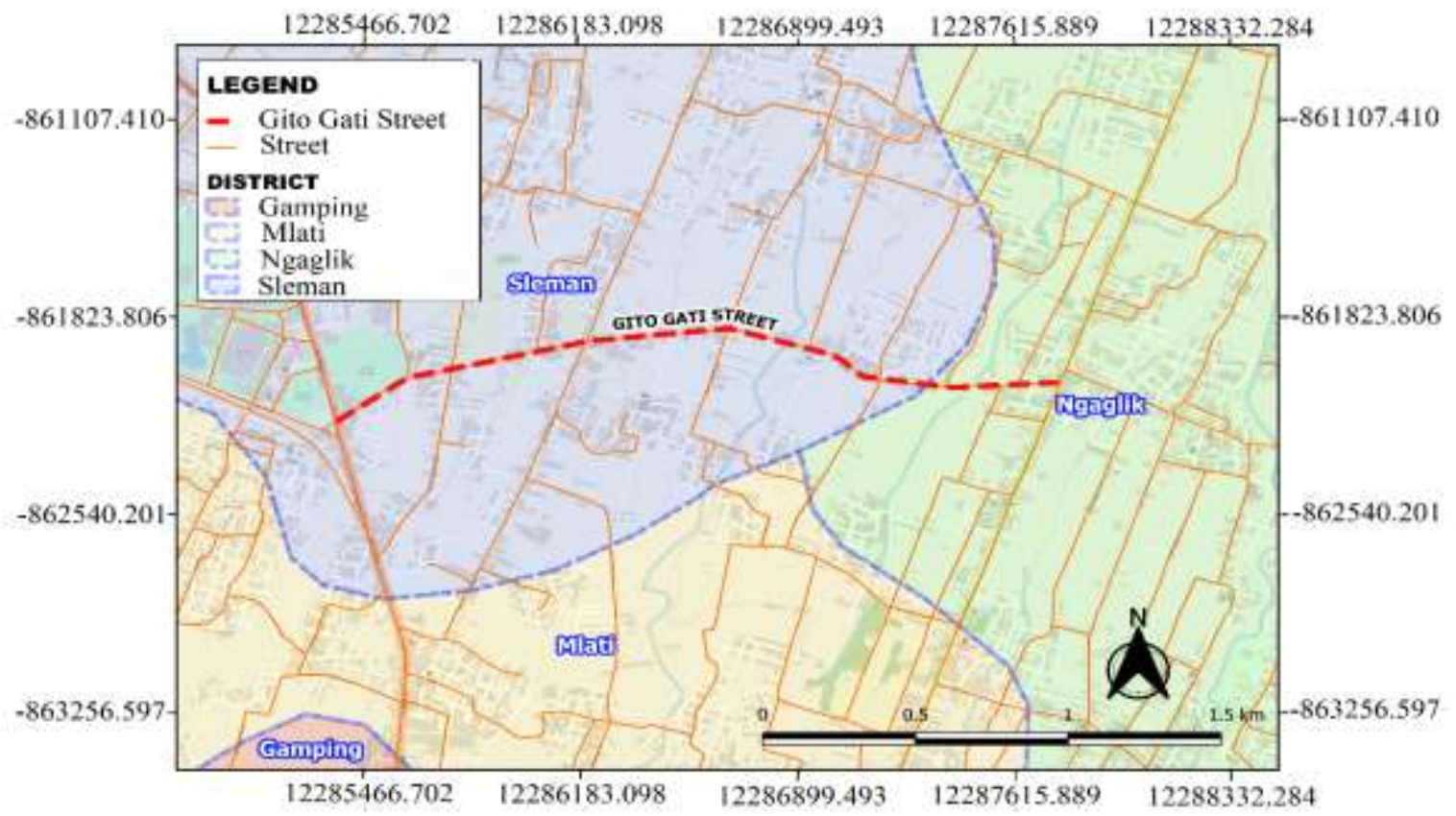

Fig. 1 Location of the study

\subsection{Type of Data}

This study utilized secondary data from the Transportation Agency and the Public Works, Housing and Energy, and Mineral Resources Agency of the Bina Marga Sector of Yogyakarta. The data used in this study consist of:

a. Average daily traffic

Daily traffic data were obtained based on secondary data from the Transportation Agency and the Public Works, Housing and Energy, and Mineral Resources Agency of the Bina Marga Sector of Yogyakarta. The recapitulation of daily traffic values in 2018 2020 is presented in Table 1.

b. Subgrade CBR value

The CBR value of the subgrade obtained from the Public Works, Housing, and Mineral Resources Energy Agency of Yogyakarta was
$13.84 \%$.

Table 1. Recapitulation of Daily Traffic

\begin{tabular}{ccc}
\hline No & Year & Daily Traffic \\
\hline 1 & 2018 & 23,808 \\
2 & 2019 & 29,520 \\
3 & 2020 & 36,867 \\
\hline
\end{tabular}

c. Pavement layer

The existing pavement layers were obtained from the Public Works, Housing, and Mineral Resources Energy Agency of Yogyakarta. Meanwhile, the material characteristics were based on MDP 2017 [20] and NCHRP 2004 [21] (Table 2).

d. Traffic growth rate

The traffic growth rate was obtained using linear regression based on the daily traffic data for 2018 - 2020 and produced a value of $10.015 \%$.

Table 2. Existing pavement data

\begin{tabular}{|c|c|c|c|c|c|c|}
\hline \multirow{2}{*}{\multicolumn{2}{|c|}{ Pavement Layer }} & \multicolumn{2}{|c|}{ Modulus of Elasticity, E (Kpa) } & \multicolumn{2}{|c|}{$\begin{array}{c}\text { Poisson's ratio, } \\
\text { u }\end{array}$} & \multirow{2}{*}{$\begin{array}{c}\text { Pavement } \\
\text { Thickness } \\
\text { (cm) }\end{array}$} \\
\hline & & Value & Source & Value & Source & \\
\hline Surface & $\begin{array}{l}\mathrm{AC}-\mathrm{WC} \\
\mathrm{AC}-\mathrm{BC}\end{array}$ & $1,200,000$ & {$[20]$} & 0.4 & \multirow{4}{*}{ [20] } & 10 \\
\hline Base & CTB & 500,000 & [20] & 0.35 & & 15 \\
\hline Sub-base & LPA Class A & 324,531 & {$[21]$} & 0.35 & & 15 \\
\hline Subgrade & & 138,400 & [20] & 0.45 & & $\infty$ \\
\hline
\end{tabular}




\section{RESULT AND DISCUSSION}

\subsection{Stress and Strain Response of Flexible Pavement}

Analysis was carried out using the KENPAVE program. It resulted in horizontal tensile strain and vertical compressive strain, as displayed in Fig 2.

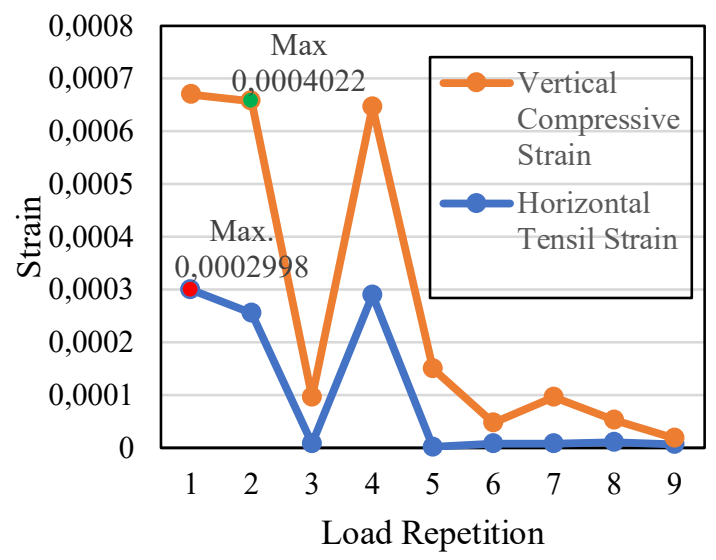

Fig 2. Output of horizontal tensile strain and vertical compressive strain

From Figure 2 it can be seen that the maximum value for the horizontal strain is 0.0002998 and the maximum value for the vertical strain is 0.0004022 . The maximum horizontal tensile strain was then used to estimate pavement fatigue life (Nf) and vertical compressive strain was then used to estimate pavement rutting life $(\mathrm{Nr})$. The results of mechanistic responses reveal that the addition of load will increase the pressure that the vehicle distributes to the pavement, so that the horizontal tensile strain and vertical compressive strain will be higher [22].

\subsection{Prediction of Remaining Service Life}

Figure 3 depicts the calculation results of the CESA4 values. Fig 2 exhibits the horizontal tensile strain and vertical compressive strain values. Meanwhile, the calculations using Eq. (1) and (2) discover the allowable load repetition values for fatigue cracking and rutting, as displayed in Table 3. The results in Fig. 3 were used to analyze the remaining service life.

Figure 3 shows that as the design life increases, the $\mathrm{CESA}_{4}$ value will increase also. The analyze the reduction in design life and the effect of pavement thickness by using the formula of design life decreasing with the value of Cumulative Equivalent Standard Axle (CESA) [23].

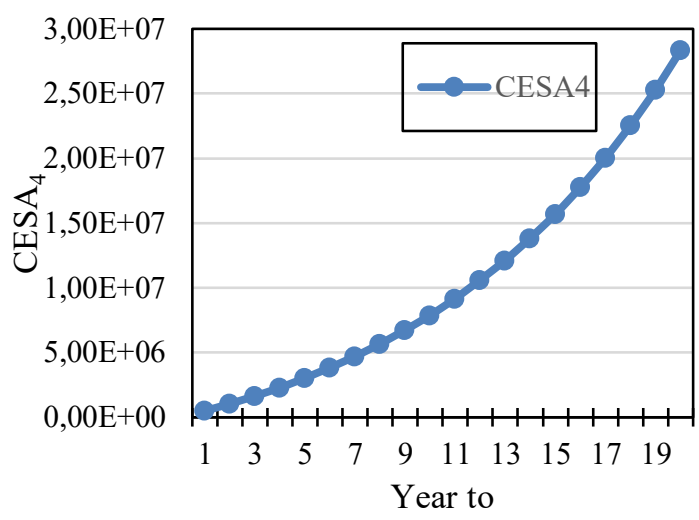

Fig 3. Recapitulation of CESA4 values for 20 years

Table 3. Repetition of load permits fatigue cracking and rutting

\begin{tabular}{cccc}
\hline \multicolumn{2}{c}{ Strain } & \multicolumn{2}{c}{ Load Repetition (ESAL) } \\
\hline$\varepsilon_{t}$ & $\mathcal{E}_{c}$ & $N f$ & $N d$ \\
0.0002998 & 0.0004022 & $1,047,484.63$ & $2,172,928.92$ \\
\hline
\end{tabular}

Figure 4 depicts the relationship between load repetition and fatigue cracking and rutting. It can be seen in Fig. 4 that the increase in load repetition value is influenced by time and will reach the repetition value of fatigue cracking load first in the second year of $1,047,484.63$, which means that the pavement will experience failure due to fatigue cracking at the beginning of the 3rd year ( 2.02 years). Rutting damage will reach a load repetition value of 2,172,928.92 in the 3rd year, which means that the pavement condition will experience failure due to rutting at the end of the 4th year (3.83 years). Table 4 displays the calculation results of the remaining service life due to traffic loads for 20 years.

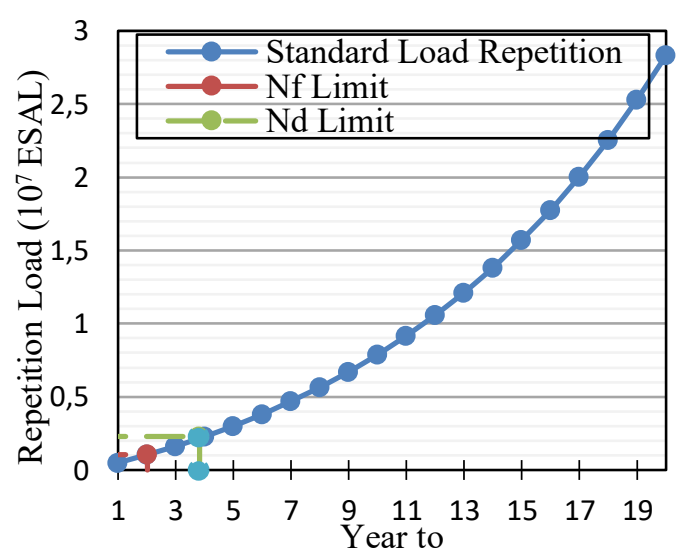

Fig. 4. Graph of the relationship between load repetition and fatigue cracking and rutting 
Table 4. The calculation results of the remaining service life due to traffic loads

\begin{tabular}{cccccc}
\hline & & \multicolumn{2}{c}{$\mathrm{N}_{1,5}$ (ESAL) } & \multicolumn{2}{c}{$\begin{array}{c}\text { Prediction of Remaining } \\
\text { Service Life (\%) }\end{array}$} \\
\cline { 3 - 5 } Year- & Np (ESAL) & $\begin{array}{c}\text { Fatigue } \\
\text { Cracking }\end{array}$ & Rutting & $\begin{array}{c}\text { Fatigue } \\
\text { Cracking }\end{array}$ & Rutting \\
\hline 1 & 493.626 & & 52.87 & 77.28 \\
2 & $1,036,688.833$ & & 1.03 & 52.29 \\
3 & $1,634,139.617$ & & & \\
4 & $2,291,425.327$ & & & \\
5 & $3,014,538.452$ & & & \\
6 & $3,810,071.634$ & & & \\
7 & $4,685,277.77$ & & & \\
8 & $5,648,136.136$ & $1,047,484.63$ & $2,172,928.92$ & & \\
9 & $6,707,425.136$ & & & \\
10 & $7,872,802.336$ & & & & \\
11 & $9,154,892.509$ & & & \\
12 & $10,565,384.505$ & & & \\
13 & $12,117,137.816$ & & & \\
14 & $13,824,299.815$ & & & \\
15 & $15,702,434.744$ & & & \\
16 & $17,768,665.606$ & & & \\
17 & $20,041,830.281$ & & & \\
18 & $22,542,653.271$ & & & \\
19 & $25,293,934.642$ & & & \\
20 & $28,320,757.897$ & & & & \\
\hline
\end{tabular}

Figure 5 demonstrates a graph of the prediction of remaining service life due to fatigue cracking and rutting.

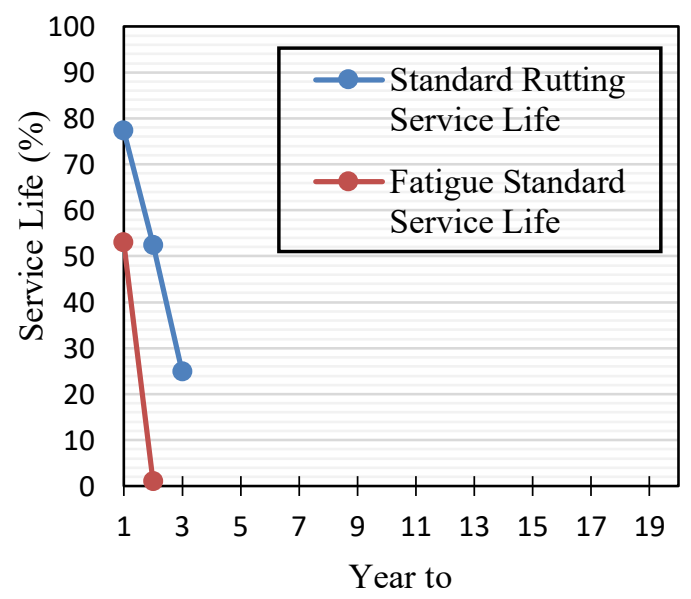

Fig. 5. Prediction graph of remaining service life due to fatigue cracking and rutting

It can be seen in Fig. 5 that the prediction of remaining service life due to fatigue cracking in year 1 is $52.87 \%$ and remaining $1.03 \%$ in year 2 , while the prediction of remaining service life due to rutting with standard load in year 1 is $77.28 \%$ and the remaining $24.79 \%$ in the 3 rd year.

\subsection{Pavement Design Manual No. 04/SE/Db/2017}

Based on the prediction of the remaining flexible pavement service life, the pavement would experience a state of failure due to fatigue cracking and rutting before the plan age of 20 years. Therefore, it is necessary to have another alternative new road capable of accommodating traffic loads to reach a design life of 20 years. The criteria for determining the type of pavement to be selected include construction costs, the type of material used, road implementation and maintenance methods, and control and supervision [24]. In the new pavement planning, the CESA5 value was used based on the fifth VDF of 33,798,952.41 ESAL, as presented in Fig 6 . The pavement thickness results are displayed in Fig. 7 and 8.

The two flexible pavement design options were analyzed with the KENPAVE program to determine the horizontal tensile stress under the surface layer and the vertical compressive strain above the subgrade. Both were calculated using Eq. 1 and 2 to obtain the repetition of allowable loads for fatigue cracking and rutting of load repetitions for the 
CESA5 plan at the design age of 20 years. The analysis results are presented in Table 5.

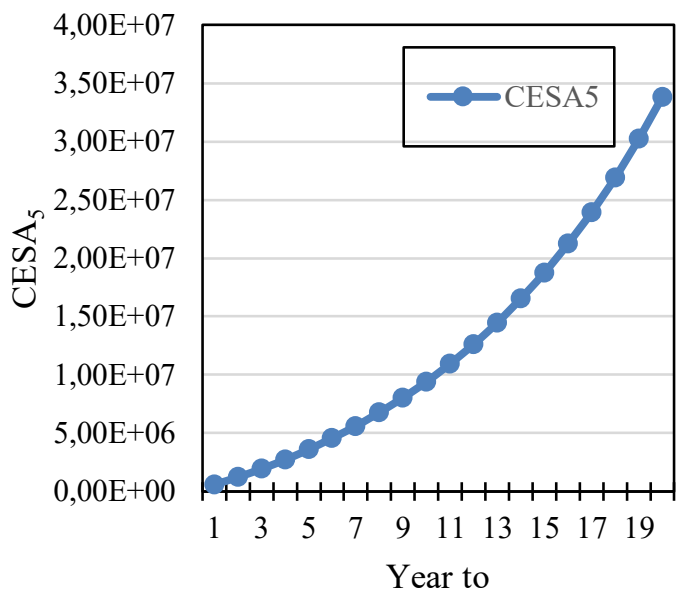

Fig 6. Recapitulation of CESA5 values
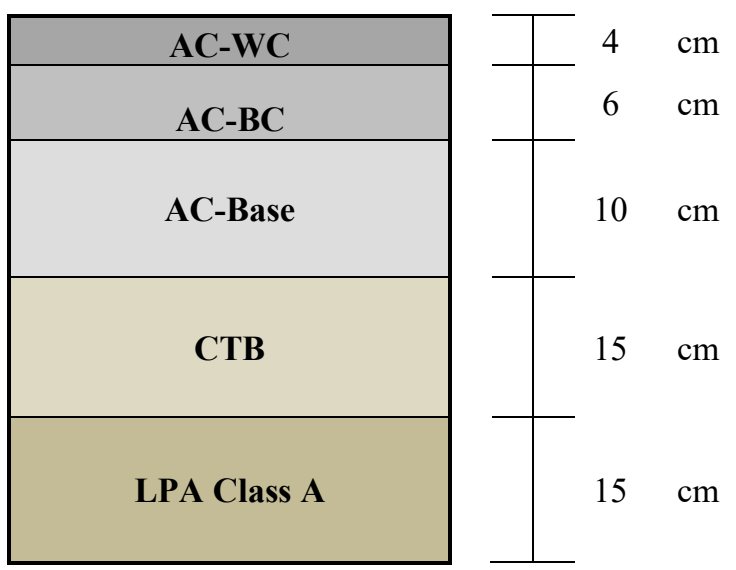

Fig. 7. Alternative treatment 1
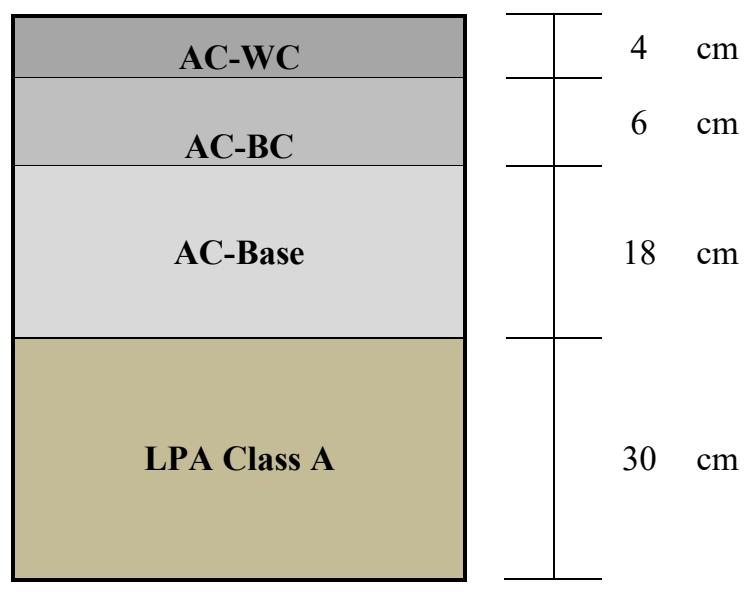

Fig. 8. Alternative treatment 2
Table 5. The results of the repetition analysis of fatigue cracking and rutting loads on the load repetition of the alternative design permits

\begin{tabular}{cccc}
\hline \multicolumn{2}{c}{ Description } & Option 1 & Option 2 \\
\hline Output & $\varepsilon t$ & 0.00009501 & 0.00009331 \\
Kenpave & $\varepsilon c$ & 0.0001979 & 0.0001912 \\
Np (ESAL) & & \multicolumn{2}{c}{$33,798,952.415$} \\
Nf (ESAL) & & $45,979,233.26$ & $48,794,051$. \\
& & & 39 \\
Nd (ESAL) & & $51,992.994 .46$ & $60,661,253$. \\
& $\mathrm{Nf}>\mathrm{Np}$ & Yes & 05 \\
Description & $\mathrm{Nd}>\mathrm{Np}$ & Yes & Yes \\
& & &
\end{tabular}

\subsection{Discussion}

Figure 2 demonstrates the results of the KENPAVE program analysis, revealing a vertical compressive strain value of 0.0004022 and a horizontal tensile strain value of 0.0002998 . These results are influenced by the thickness of the pavement layer, modulus of elasticity, and Poisson's ratio.

Table 4 depicts the CESA4 value of $28,320,757,897$ ESAL for the plan age of 20 years. Table 4 also displays a repetition of an allowable load of 1,047,484.63 ESAL for fatigue cracking and 2,172,928.92 ESAL for rutting. These results indicate that the pavement will collapse due to fatigue cracking first with a load repetition value of 1,047,484.63 ESAL and cracking with a load repetition value of 2,172,928.92 ESAL. In short, the pavement is unable to accommodate the load.

Figure 4 demonstrates that the increase in load repetition value is influenced by time and will reach a repetition value of fatigue cracking load of $1,047,484.63$ in the second year. It implies that the pavement will experience failure due to fatigue cracking at the beginning of the third year (2.02 years). Rutting damage will reach a load repetition value of 2,172,928.92 in the third year, indicating that the pavement condition will experience failure due to rutting at the end of the fourth year (3.83 years). With a design life of 20 years, DenggungWonorejo Street is unable to accommodate the repetition loads due to fatigue cracking and rutting.

Figure 5 implies that the prediction of remaining service life due to fatigue cracking is $52.87 \%$ in the first year and $1.03 \%$ in the second year. On the other hand, the prediction of remaining service life due to rutting with standard loads is $77.28 \%$ in the first year and $24.79 \%$ in the third year. These study results are in line with previous research, stating that the load repetition would increase with pavement age and would experience failure when reaching the allowable load repetition [25].

Table 5 demonstrates that the repetition values of the fatigue cracking loads (Nf) and the cracking 
loads $(\mathrm{Nd})$ are greater than the repetition values of the plan loads (Np) for both options 1 and 2. Hence, both options are recommended as alternative treatments for Denggung - Wonorejo Street, with a design life of 20 years. The cost of pavement using a CTB base layer is generally cheaper than pavement with a grained base layer. However, contractors who can carry out CTB are limited due to limited resources. In addition, CTB can save on the use of asphalt and grained materials. It also has a faster service life. Moreover, the nature of CTB is also insensitive to water, resulting in a relatively more stable structure in the summer or rainy season, and the modulus of the CTB layer is higher than that of the aggregate base layer $[20,26]$. Therefore, option 1 pavement with CTB is more recommended than option 2 .

\section{CONCLUSION}

The following conclusions were drawn based on the research results.

a. The flexible pavement on Denggung - Wonorejo Street responded to traffic loads in the form of the horizontal tensile strain of 0.0002998 with an allowable load repetition value of 1,047,484.63 ESAL and a vertical compressive strain value of 0.0004022 with an allowable load repetition value of 2,172, 928.92 ESAL.

b. The prediction of the remaining service life due to traffic loads at standard loads was $1.03 \%$ of fatigue cracking at the end of the second year and $24.7 \%$ of rutting at the end of the third year. It indicates that this study location is unable to accommodate the repetition loads caused by fatigue cracking and rutting.

c. Both alternative handling options 1 and 2 are recommended as treatments for the DenggungWonorejo Street with a repetition value of fatigue cracking loads of 45,979,233.26 ESAL for option 1 and 48,794,051.39 ESAL for option 2 , and the repetition value of rutting loads of 51,992,994.46 ESAL for option 1 and $60,661,253.05$ ESAL for option 2. However, option 1 is more recommended than option 2 .

\section{REFERENCES}

[1] Ameri, M., \& Khavandi, A. (2009). Development of mechanistic-empirical flexible pavement design in Iran. Journal of Applied Sciences, 9(2), 354-359.

[2] Huang, Y. H. (2004). Pavement analysis and design. Englewood Cliffs, NJ: Prentice Hall.

[3] Ramyashree, P. H., (2016). Analysis on Performance of Terrazyme Stabilized Soil by Using KENPAVE Software. International Journal of Engineering Science, 6(10), 2729.
2732.

[4] SKBI, D. P. U. (1987). 2.3. 26.1987, UDC. 625.73 (02). SNI 1732-1989-F, Yayasan Badan Penerbitan PU,"Petunjuk perencanaan tebal perkerasan lentur jalan raya dengan metode analisa komponen Jakarta.

[5] Heliyati, C. A., \& Kushari, B. (2016). Perbandingan Perencanaan Tebal Perkerasan Lentur Jalan dengan Metode Empirik dan Mekanistik-Empirik Pada Ruas Jalan MlatiCebongan-Seyegan. In Prosiding Forum Studi Transportasi antar Perguruan Tinggi.

[6] Gupta, A., Kumar, P., \& Rastogi, R., 2015. Mechanistic-Empirical Approach for Design of Low Volume Pavements. International Journal of Pavement Engineering, 16(9), 797808.

[7] Gedafa, D. S. (2007). Performance prediction and maintenance of flexible pavement. Proceedings of the 2007 Mid-Continent Transportation Research Symposium, Ames, IA, USA.

[8] Rind, T. A., Memon, N. A., \& Qureshi, A. S. (2017). Analysis and Design of Flexible Pavement Using Empirical-Mechanistic Based Software (KENPAVE). International Conference on Sustainable Development in Civil Engineering.

[9] Muniandy, R., Aburkaba, E., \& Thamer, N. (2013). Comparison of flexible pavement performance using Kenlayer and Chev PC software program. Australian Journal of Basic and Applied Sciences, 7(9), 112-119.

[10] Al-Khateeb, L. A., Saoud, A., \& Al-Msouti, M. F., 2011. Rutting Prediction of Flexible Pavements Using Finite Element Modeling. Jordan Journal of Civil Engineering, 5(2), 173-190.

[11] Adlinge, S. S., \& Gupta, A. K., 2013. Pavement deterioration and its causes. International Journal of Innovative Research and Development, 2(4), 437-450.

[12] Behiry, A. E. A. E.-M. (2012). Fatigue and rutting lives in flexible pavement. Ain Shams Engineering Journal, 3(4), 367-374.

[13] Chegenizadeh, A., Keramatikerman, M., \& Nikraz, H. (2016). Flexible pavement modelling using Kenlayer. EJGE, 21, 24672479.

[14] Rind, T. A., Jhatial, A. A., Sandhu, A. R., Bhatti, I. A., \& Ahmed, S. (2019). Fatigue and Rutting Analysis of Asphaltic Pavement Using "KENLAYER" Software. Journal of Applied Engineering Sciences, 9(2), 177-182.

[15] Srikanth, M. (2015). Study on Effect of Surface Course Thickness and Modulus of Elasticity on Performance of Flexible Pavement using a Software Tool. International Journal of Engineering Research \& 
Technology, 4(08), 771-774.

[16] Motaleb, M. E.-S. A. (2010). Development of Contractor Payment Method Based On Pavement Performance.

[17] Asphalt Institute. (1981). Thickness Design: Asphalt Pavements for Highways and Streets (Vol. 1). Lexington: Asphalt Institute.

[18] AASHTO. 1993. AASHTO guide for design of pavement structures. Washington: AASHTO.

[19] Sukirman, S. (1999). Perkerasan lentur jalan raya. Bandung: Nova.

[20] Kementerian Pekerjaan Umum Direktorat Jenderal Bina Marga. 2017. Manual Desain Perkerasan Jalan Nomor 04/SE/Db/2017. Jakarta.

[21] NCHRP (2004) Guide for mechanisticempirical design of pavement structures. National cooperative highway research program. ARA, Inc., ERES Consultants Division, Champaign, IL

[22] Tajudin, A. N., Setyarini, N.L., and Darmawati, D.S., (2018). The Influence of CBR Value and Overloading on Flexible Pavement Mechanistic Response. Advances in
Engineering Research, (Vol 186).

[23] Rahmawati, A., Adly, E., Lutfiyanto, I., and Syifa, M., (2019), The Overloading Effect on the Design Life of Road and Thickness of Pavement Layer, IOP Conference Series: Materials Science and Engineering, 650, 012051

[24] Susanto, Dandoko Hadi (2012). Analisis Keputusan Pemilihan Konstruksi Perkerasan Jalan dengan Metode Analytic Hierarcy Process (AHP) (Studi Kasus Dinas PU. Bina Marga Kab. Lamongan).

[25] Usman, R., Setyawan, A., \& Suprapto, M. (2018). Prediction of pavement remaining service life based on repetition of load and permanent deformation. IOP Conference Series: Materials Science and Engineering

[26] Nono, S. (2009). Kajian Penggunaan Lapis Pondasi Agregat yang Distabilisasi Semen. Pusat Litbang dan Jembatan. Bandung.

Copyright (C) Int. J. of GEOMATE All rights reserved, including making copies unless permission is obtained from the copyright proprietors. 